\section{Tamara Gvozdenović ${ }^{1}$ Vedran Furtula Gojko Krunić}

\title{
IMPROVEMENT OF WATER SUPPLY SYSTEM AND WATER QUALITY SYSTEM FOR THE CITY OF TREBINJE BY CONSTRUCTION OF WATER FACILITY RESERVOIR VRELO OKO
}

\begin{abstract}
Water supply system in the city of Trebinje has been developed during a longer time period and has been rather underdeveloped compared to the development of the city. With construction of a new water reservoir of potable water "Vrelo oko" water supply system of the city of Trebinje will be substantially improved. Apart from a new reservoir to be constructed, a new penstock toward the reservoir will be constructed, as well as a total reconstruction of hydromechanical equipment for pump station, including a new pump installation. A new chlorinator is planned to be constructed for water chlorination and a total automatization of the facility will be completed, which will additionally ensure safety at work. This water system reservoir will have a role as primary precipitator to a certain extent which will improve water quality in periods of high precipitation and water source gets mudded.
\end{abstract}

Keywords: water supply system, water quality, water system reservoir

\section{Introduction}

Urban water supply system of Trebinje, supplies city of Trebinje and its vicinity with water from karst spring Vrelo Oko, which is located cca $7 \mathrm{~km}$ upstream from the town. Basic feature of the spring is that it is a constant spring of benign temperature, colourless, clear, of moderate hardness and of good taste. River basin of spring Vrelo Oko encompasses mountain area between Bijela gora and Zubci. Spring karst water is subject to intermittent puddling, resulting from storm waters and lasting for few days. Puddling is mainly of inorganic origin, namely, it is in fact melted particles or partially melted particles and is considered to be harmless for health, but nevertheless, consumers are timely informed to boil potable water as a prevention.

Inhabitants living out of water supply system zone get water supplies from tanks (small reservoirs), karst springs and small local supply systems. Water supply system in Trebinje has developed over long time period and has been underdeveloped compared to town development. Nowadays water supply system in Trebinje with settlements in the vicinity has developed water supply pipeline of cca $120 \mathrm{~km}$ (pipeline larger than 2"), which is made of various materials: steel, asbestos-cement, PVC, PE and other materials. Chlorination in chlor station is done automatically, ie.

\footnotetext{
${ }^{1}$ Corresponding author: Tamara Gvozdenović

Email: tgvozdenovic@ henatrebisnjici.com
} 
related to water flow. Water gauge is located at the outlet from pump station. Chlorination is not well arranged, because one water gauge is located at outlet pipeline, while water flows through two pipelines to reservoir. Chlorinated water is well mixed only in the mentioned reservoir. (Consortium, 2016)

Water supply system has been developed according to short termed requirements and financial capacities, without envisaging the system as a whole. According to the last official census in 1991, municipality of Trebinje had 30.996 inhabitants. According to preliminary results of census in 2013, municipality of Trebinje had 31.433 inhabitants. In recent years, potable water is deficient with consumers, so it is necessary to increase propulsiveness of pipeline under pressure and gravitational pipeline.

\section{Development of water supply system in Trebinje}

First research for project design for water supply in Trebinje was done in 1898, and it was already the next year that spring "Oko" was captured (it is located $7 \mathrm{~km}$ east of the town centre) which according to measurements was abounding during summer with $800 \mathrm{l} / \mathrm{s}$, with constant water temperature of $9^{\circ} \mathrm{C}$. Construction of water supply system began in 1902. and the water supply system was put into operation in November $18^{\text {th }} 1903$. Water from spring "Oko" was transferred with pressure into reservoir "Oko" by a pump station, where from it was transferred to town reservoir "Krš" by gravitational pipeline in length of $6500 \mathrm{~m}$.

According to statistical data from 1895. town centre without suburban areas had 3000 inhabitants and this was base for calculations of amounts of water requirements. Reservoir capacity in town read $80 \%$ of daily consumption average. Until 1955, this condition of water intake, water transport to consumers and reservoir were not changed. In 1955 a new pipeline under pressure was built on pump station "Oko" and supply pipeline made of cast steel. A new reservoir "Hrupjela" volume of $400 \mathrm{~m}^{3}$ was built.

Upon construction of "Gorica" dam, an accumulation was formed which flooed wate capture and pump station "Oko", and part of pressure pipeline and transfer pipeline, and in 1965 it was reconstructed again. A new pump station was constructed which was out or reach of accumulation level. Maximum accumulation level is 295 a.s.l., and new pump station is at 302 a.s.l. Spring "Oko" was captured by vertical heading. Flooded parts of pressured and gravitational pipeline are dislocated out of accummulation. Into pipe columns $\varnothing 500 \mathrm{~mm}$ pumps are flooded into underground spring out of which water is being pumped and transferred by penstock into reservoir "Oko". From reservoir "Oko" water by gravitation comes to reservoir "Krš". Gravitational pipeline is constructed from reservoir "Oko" near accumulation, made from cast steel pipes profiles $\varnothing 250$ $\mathrm{mm}$, which was built in 1955. (Energoinvest Sarajevo, 1964)

Natural water regime of spring "Oko" is imbalanced after construction of accummulation "Trebinje", which effected in a totally different and more difficult way of water exploitation for potable water for inhabitants and industry of town Trebinje.

In 1972 another reconstruction was done on main supply pipeline, approximately near the half of the conduit run looking from the "Kršs" reservoir toward spring "Oko". On this section, pipeline of profile $\varnothing 500 \mathrm{~mm}$ was installed, and in 1978 pipeline of profile $\varnothing 600 \mathrm{~mm}$ on the conduit run starting from the reservoir "Oko" to Lučin Do. Pump station was built in 1991 and its area is cca $200 \mathrm{~m}^{2}$. (Geotehnika Zagreb, 1979, 1990)

Nowadays water supply system Trebinje with surrounding settlements has pipeline of length cca $120 \mathrm{~km}$ (pipelines wider than 2“), that was made of various material types: 


\section{Intermational Cualily Conference}

Q UA I II TY DIFSIFAIDCI-

steel, asbestos - cement, PVC, PE and other materials.

Within the spring area there are six drills which are directly connected with the spring.
Five pumps are installed in the drills (pump characteristics are presented in Table 1) at the depth of cca $42 \mathrm{~m}$ from the soil surface level.

Table 1. Pump characteristics within spring Vrelo Oko (Consortium, 2016)

\begin{tabular}{|c|c|c|c|c|c|}
\hline $\begin{array}{c}\text { Pump } \\
\text { number }\end{array}$ & Manufacturer & Type & $\begin{array}{c}\text { Pump power } \\
\text { Np (KW) }\end{array}$ & $\begin{array}{c}\text { Pump runout } \\
\text { Qp }(1 / \mathrm{s})\end{array}$ & $\begin{array}{c}\text { Lifting height } \\
\text { H(m) }\end{array}$ \\
\hline Pump No. 1 & KSB & UPA 350-180/2A & 180 & 180 & 77 \\
\hline Pump No. 2 & KSB & UPA 350-180/2A & 175 & 180 & 76 \\
\hline Pump No. 3 & SAER & $\begin{array}{c}\text { SPC 252A/3A } \\
\text { HP100 }\end{array}$ & 75 & 75 & 72 \\
\hline Pump No. 4 & KSB & UPA 250C-250/3 & 72 & 73 & 74 \\
\hline Pump No. 5 & SAER & S 252S/3B HP90 & 67 & 84 & 72 \\
\hline
\end{tabular}

Within pump station there is a control area for handling the pumps and for running the pumps. The system is connected by telemetry - running of the pump and the reservoir. Within the reservoir there is a water level gauge which gives the information for turning on the pumps, and vice versa, for turning off the pumps. Within this construction there is a reservoiri cca 250 $m$ distant with capacity of $400 \mathrm{~m}^{3}$. This reservoir was constructed in 1908. Reservoir area is in bad condition, but due to its constant operation, it is difficult to define whether it is water impermeable or not. Also, hydro-mechanical equipment should be repaired or replacement of some components, especially armature.

A pipeline comes out of pump station, pipes of $\varnothing 600 \mathrm{~mm}$ which diverges into three pipelines. One pipeline is of $\varnothing 300 \mathrm{~mm}$ and two pipelines of $\varnothing 500 \mathrm{~mm}$ out of which one pipeline is sealed (blocked) $30 \mathrm{~m}$ away from the pump, so that two pipelines run to the reservoir. There is a pressure tank on the outflow pipeline functioning as protection from hydraulic shock. (Consortium, 2016)

Chlorinator is located between reservoir and pump station. Chlorination is done automatically with gas chlorin, ie. in relation to flow. Water flow gauge is installed at the outlet of the pump station. Chlorination is not distributed in a good manner, for one water flow gauge is installed at the outage pipeline, while water flows through two pipelines toward reservoir. Chlorinated water is well mixed only in the forementioned reservoir.

Transport pipeline from old reservoir (Vrelo Oko 1) is of $\varnothing 600 \mathrm{~mm}$ also in division shaft in front of reservoir, and outside the barrier it is connected to existing transport pipeline of $\varnothing 600 \mathrm{~mm}$ which runs to reservoir and pump station "Krš" and distributive pipeline of $\varnothing 300 \mathrm{~mm}$ which supplies alongside consumers and is also connected to reservoir and pump station "Kršs".

\section{Characteristics of spring Vrelo Oko}

Main characteristics of this spring is that this water is constant, of benign temperature, colourless, clear, of moderate hardness and good taste. Water from karst springs contain some quantity of melted minerals, that give this water excellent taste. When it comes to melted minerals, water from spring Vrelo Oko belongs to moderate hard water, its hardness ranges from $8-10,5^{\circ} \mathrm{dH}$.

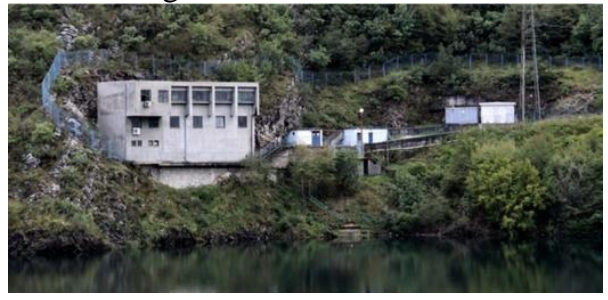

Figure 1. Spring Vrelo Oko 
Catchment area of spring Vrelo oko encompasses mountain region between Bijela gora and Zubci. Terrain of the catchment is still wild nature without any urban agglomeration, and no dangerous substances have been detected up to nowadays, so the water from the depth of spring is of good quality, and is not exposed to any treatment, except disinfection with gas chlorine within boundaries set by law. Spring karst waters are subject to transient temporary puddling, which appears after heavy storms and lasts few days. (Milanović, 2006) The puddling is mainly of inorganic origin, namely, it is in fact melted particles or partially melted particles and is considered to be harmless for health, but nevertheless, consumers are timely informed to boil potable water as a prevention. In Table 2 evidenced puddling at spring Vrelo Oko for time period from 2007. to 2018. are presented.

Table 2. Evidenced puddling of water at spring Vrelo Oko for time period from 2007. to 2018. (Vodovod Trebinje, 2019)

\begin{tabular}{|c|c|c|c|c|}
\hline $\begin{array}{c}\text { Appearance of } \\
\text { puddling in years }\end{array}$ & $\begin{array}{l}\text { Time period of puddling } \\
\text { appearance }\end{array}$ & $\begin{array}{l}\text { Total days } \\
\text { a year }\end{array}$ & $\begin{array}{l}\text { Total times } \\
\text { a year }\end{array}$ & $\begin{array}{l}\text { Number } \\
\text { of } \\
\text { analysis }\end{array}$ \\
\hline 2007 & $\begin{array}{c}\text { 21.02.-06.03; 21.03.-22.03.; } \\
\text { 03.10.-17.10. }\end{array}$ & 28 & 3 times & 32 \\
\hline 2008 & 24.03.-25.03; 26.11.-03.12. & 9 & 2 & 35 \\
\hline 2009 & 13.10.-15.10;06.11.-10.11. & 8 & 2 & 43 \\
\hline 2010 & $\begin{array}{l}\text { 17.05.-19.05;09.11.-15.11.; } \\
\text { 23.11.-25.11;02.12.-07.12. }\end{array}$ & 19 & 4 & 40 \\
\hline 2011 & 26.04.; 10.06.-13.06. & 4 & 2 & 47 \\
\hline 2012 & 17.04.-19.04. & 3 & 1 & 36 \\
\hline 2013 & $\begin{array}{c}\text { 16.01.-23.01. ; 25.02.-28.02. ; } \\
\text { 19.03.-21.03 }\end{array}$ & 12 & 3 & 38 \\
\hline 2014 & $\begin{array}{c}\text { 20.01.-27.01. ; 28.07. ; 04.08.; } \\
\text { 02.09.-03.09; 12.09.-14.09.; } \\
\text { 30.11.-08.12 }\end{array}$ & 20 & 6 & 38 \\
\hline 2015 & $\begin{array}{c}19.01 .-21.01 . ; 23.02 .-24.02 . ; \\
16.10 .-26.10\end{array}$ & 13 & 3 & 37 \\
\hline 2016 & $\begin{array}{c}\text { 07.03.-14.03; 21.10.-25.10.; } \\
\text { 14.11.; 22.11. }\end{array}$ & 13 & 4 & 37 \\
\hline 2017 & $\begin{array}{c}\text { 27.02.-03.03; } 14.11 .-20.11 . ; \\
01.12 .-06.12 ; 26.12 .\end{array}$ & 17 & 3 & 37 \\
\hline 2018 & $\begin{array}{c}\text { 29.10.-06.11; 20.11.-23.11.; } \\
\text { 26.11.-29.11. }\end{array}$ & 15 & 3 & 39 \\
\hline
\end{tabular}

During the foregoing time period, all other physical - chemical indicators, were in line with the Manual except abstracted puddlings, with exception of three samples where increased value of ammonia was found besides puddling (as bolded in the table). (Vodovod Trebinje, 2019)

Public enterprise "Vodovod" cannot influence these puddlings, but following legal acts, it always acts to prevent health of consumers. At such occasssions, process of disinfection is closely controlled, and number of analysis of the spring water is increased as well, and the so called extraordinary analysis of water compounds.

\section{Water quality control}

Institute for public health Banja Luka, Regional centre Trebinje, performs water quality control for public health, which is 


\section{International Quality Conference}

licenced for such activity, in line with Manual on hygiene soundness of drinking water. (Vodovod Trebinje, 2019) The present Manual defines scope, frequency, number and type of analysis. Public sanitary quality control of water from city water supply system is performed at several levels, namely:

- Analyses of Basic examination (A), Public health Institute of Republic of Srpska in Banja Luka, Regional centre in Trebinje performs during a year;

- Analises of periodical examination (B) (higher level of water quality control), is performed by Public health Institute of Republic of Srpska in Banja Luka;

- Internal control, ie. monitoring of water quality and process of disinfection, ie. control of quantity of residual chlorine in complete system of water supply, is performed daily by internal laboratory of the enterprise;

- Extraordinary controls are performed at times of torrents or other accidental contaminations in broader catchment area. (Official Gazette of Republic of Srpska)

Quality control is done from the following spots: (Vodovod Trebinje, 2019)

- Water spring Vrelo oko, ie. natural water before disinfection is done;

- Water from tank of chlorinated water (reservoir);

- Water from location of consumption (faucet) taking into account that all parts of town are covered, as well as all public facilities (schools, kindergartens, health centres and the similar places) as well as other economic facilities and other objects;

- Water taken from new sections of pipeline and newly built objects.

A complete insight into hygiene soundness of drinking water is thus obtained starting from the spring to consumer's faucet.

In 2018 in licenced Public health institute were examined 292 samples of water for physical-chemical analysis and 297 samples of water for microbiological analysis from city water supply system. (Table 3 ).

Table 3. Review of number of analysed samples of drinking water in 2018 (Vodovod Trebinje, 2019)

\begin{tabular}{|c|c|c|c|c|}
\hline \multirow[b]{2}{*}{ Samples of water } & \multicolumn{2}{|c|}{ Basic physical-chemical analyses (A) } & \multicolumn{2}{|c|}{ Basic micro-biological analyses (A) } \\
\hline & $\begin{array}{l}\text { Number of } \\
\text { analysed samples }\end{array}$ & $\begin{array}{c}\text { Number of } \\
\text { unsound } \\
\text { samples }\end{array}$ & $\begin{array}{l}\text { Number of } \\
\text { analysed } \\
\text { samples }\end{array}$ & $\begin{array}{c}\text { Number of } \\
\text { unsound } \\
\text { samples }\end{array}$ \\
\hline Reservoir & 73 & 6 & 74 & 1 \\
\hline Supply system & 176 & 4 & 180 & 2 \\
\hline Natural water & 38 & 3 & 38 & 14 \\
\hline \multirow[b]{2}{*}{ Samples of water } & \multicolumn{2}{|c|}{$\begin{array}{l}\text { Periodical physical-chemical analyses } \\
\text { (B) }\end{array}$} & \multicolumn{2}{|c|}{$\begin{array}{l}\text { Periodical micro-biological analyses } \\
\text { (B) }\end{array}$} \\
\hline & $\begin{array}{l}\text { Number of } \\
\text { analysed samples }\end{array}$ & $\begin{array}{c}\text { Number of } \\
\text { unsound } \\
\text { samples }\end{array}$ & $\begin{array}{l}\text { Number of } \\
\text { analysed } \\
\text { samples }\end{array}$ & $\begin{array}{l}\text { Number of } \\
\text { unsound } \\
\text { samples }\end{array}$ \\
\hline Reservoir & 4 & 0 & 4 & 0 \\
\hline Natural water & 1 & 0 & 1 & 0 \\
\hline Total & 292 & $10+3$ & 297 & $3+14$ \\
\hline
\end{tabular}

While evaluating natural water, according

to the rules of accreditation observed in 
Public health institute of RS in Banja Luka, evaluation of natural water quality is not done when it comes to microbiological and physical-chemical soundness (results of analyses are presented only), but the law-maker introduced obligatory adequate technical procedure which enables hygienic soundness of drinking water that may not be epidemically dangerous, ie. drinking water must be safe for end user from aspect of consumer's health. (Vodovod Trebinje, 2019)

Table 3 shows that certified percentage of chlorinated water samples that were not sound was very small. Physical - chemical unsoundness is found with ten (10) samples or $3,95 \%$. The cause of unsoundness is slightly increased puddling, which appeared after heavy torrents. Microbiological unsoundness is found with only three (3) samples or with $1,16 \%$, reffering mainly to samples taken from outer faucets, so it is reasonable to suspect that the problem is in the fixtures inside the facility or some transient dirtiness of local character, a phenomenon that is usual with water supply system. Repeated analyses of the same spots have showed hygiene soundness.

Five (5) analyses of Periodical (B) examination of drinking water were done by Public health institute of RS in Banja Luka. All analyses indicated hygienic soundness of the water.

Based on given results of basic (A) and periodical (B) examination of chlorinated water, it could be concluded that quality of drinking water under standard hydrological period is extremely good.

Percentage of unsound samples is very small, and it is far smaller than the percentage tolerated by World Health Organisation, for according to World Health Organisation (WHO) microbiologic unsoundness with central water supply systems are tolerated by $5 \%$ at yearly level and physical-chemical unsoundness is tolerated to $20 \%$, whereby water quality at spring is not taken into account, due to opinion that the water at spring is hygienically not sound as a rule and this is why this water has to be subject to adequate treatment. (Vodovod Trebinje, 2019) In order to obtain hygienically sound drinking water, enterprise Vodovod, performs projected cleaning, washing and disinfection of water facilities (reservoir), as well as rinsing out of transport pipeline and distribution pipeline (network).

\section{Construction of water system reservoir Vrelo Oko}

With a view to improve quality of water supply and to overcome shortage of drinking water that was increasing in recent years, works were undertaken in the town.

A number of constructional projects are under works, reconstruction and upgrading of water supply system in Trebinje, investors being the city of Trebinje and Public enterprise Vodovod Trebinje, some of them are the following: (Gvozdenović et al., 2019)

- Construction of new reservoir of drinking water Vrelo Oko 2,

- Construction of new water supply system on the right bank of the river Trebišnjica (Hrupjela, Podgljivlje, Vinogradi),

- Construction of new water supply system on the left bank of the river Trebišnjica ( Gorica dam, Police) and

- Construction of new water supply system toward Draženska Gora and Grad Sunca.

The most important of all aforementioned projects is construction of new reservoir of drinking water Vrelo Oko 2, financed by Hydro Power Plants on the river Trebisnjica, whose construction began at 


\section{Intermational Quality Conference}

RUA IITY

the end of the last year. Water supply system will be significantly improved by construction of new reservoir Vrelo Oko 2.

Newly projected condition represents reconstruction of the present system at pump station Vrelo Oko, old reservoir Vrelo Oko 1, ie. joint manhole in front of the same, and construction of new reservoir Vrelo Oko 2 whose volume is $2 \times 2500 \mathrm{~m}^{3}$.

New reservoir (Vrelo Oko 2) is located cca $20 \mathrm{~m}$ to the south from the old reservoir (Vrelo Oko 1). Thus possible problems with safety and stability of the old and time-worn reservoir are overcome. Though two reservoirs are two separate facilities, the area of the reservoirs is increased by constructing reservoir Vrelo Oko 2.

The present method of capturing water from spring is changed and a technical solution with two separate pump systems is done. Under new technical solution pumps number 3, 4 and 5 make one system and they will supply reservoir Vrelo Oko 1 whose volume is $400 \mathrm{~m}^{3}$. The pumps would pump using the system $2+1$ (two operational pumps + one spare pump) at the level 333,61 $\mathrm{m}$ a.s.l. Pumps number 1 and 2 "of big capacity" (also 2+1) would supply reservoir Vrelo Oko 2, whose volume will be $2 \times 2500 \mathrm{~m}^{3}$ and level of spillway $338,20 \mathrm{~m}$ a.s.l.

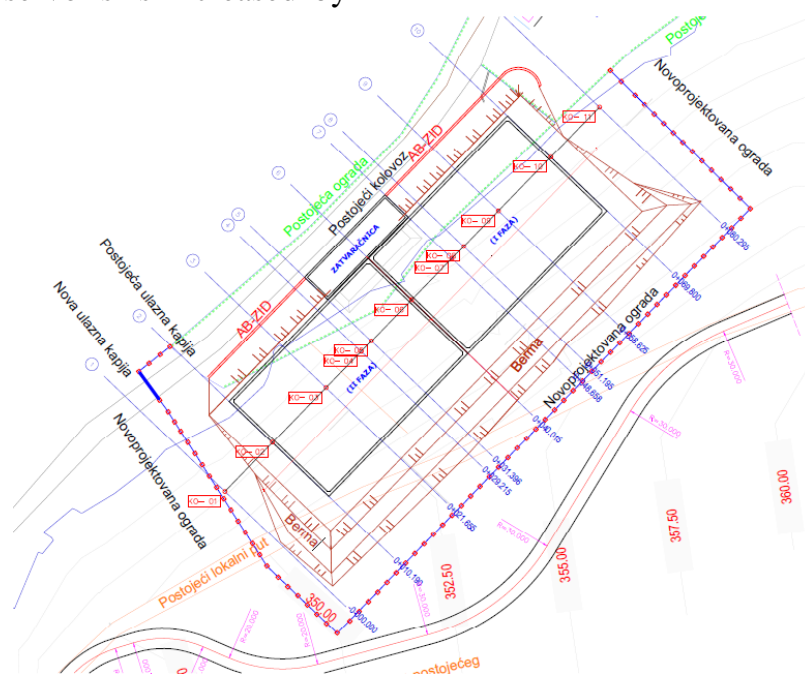

Figure 2. Layout of reservoir Vrelo Oko 2 (Consortium, 2016)

It is projected for the pump station of "big" pumps, one more pump to be installed within present draw well. Capacity of new pump is $\mathrm{Qp}=185 \mathrm{l} / \mathrm{s}$, and height of lifting $\mathrm{H}=80,59 \mathrm{~m}$. Existing pumps of bigger capacity will not loose their projected capacity with delevelling of spillway level in reservoir Vrelo Oko 2. It is also projected electromotive gate valves to be installed at each outlet pipeline instead of existing gate valves.
Reservoirs will be equipped with adequate pressure vessels (system protection in case of hydraulic shock), as well as other hydromechanics equipment (compressors, hoisting devices, gauge flows, gate valves and other equipment).

Present system has one pressure vessel, and separating the system into two systems, effected in requirement to install another pressure vessel. Capacity of pressure vessel for reservoir Vrelo Oko 1 
reads 5001 with inlet/outlet of $\varnothing 100 \mathrm{~mm}$, and for reservoir Vrelo Oko 2 it is 25001 with inlet/outlet of Ø200 mm.

In the pump station almost all external elements and fixtures will be replaced (total reconstruction), and also automotive elements will be installed, so that this facility makes a whole in management sense (pump station, reservoir Vrelo Oko 1, reservoir Vrelo Oko 2).

New station for chlorination is planned to be constructed and also automotive chlorination of both pipelines separately, depending on flow, where control of mixing chlorine and water would be performed.

Upon completion of reservoir, pressure pipeline, gravity pipeline and puddling pipeline (for slurry water) will be installed from reservoir Vrelo Oko 1 to reservoir Vrelo Oko 2. Existing pressure pipeline is planned to be replaced by pipeline from nodular cast "ductile". Length of pressure pipeline for reservoir Vrelo Oko 1 is 224 $\mathrm{m}$ DN $500 \mathrm{~mm}$ NP 10 bars, with appropriate external elements. Length of pressure pipeline for reservoir Vrelo Oko 2 is $273 \mathrm{~m} \mathrm{DN} 500 \mathrm{~mm} \mathrm{NP} 10$ bars with appropriate external elements. (Consortium, 2016)

Out of reservoir Vrelo Oko 2 there is distributive pipeline DN600 mm in length of $60 \mathrm{~m}$, to cumulative (split) shaft. Out of cumulative shaft, water will be gravity distributed toward town Trebinje by previously described transport and distribution pipelines respectively.

\section{Conclusion}

Aiming to greatly improve stability of water supply in the area of Trebinje town, in November 2018 works on construction new reservoir for drinking water Vrelo Oko 2 began. Capacity of new reservoir is $2 \times 2.500 \mathrm{~m}^{3}$ of water.

Besides construction of new reservoir, a new pressure pipeline will be constructed toward reservoir, and total reconstruction of hydromechanical equipment of pump station will be performed, including installation of new pump with capacity of $185 \mathrm{l} / \mathrm{s}$. A new chlorinator is projected to chlorinate water and total automation of facility, which will additionally obtain safety at work. Construction of new reservoir will substantially decrease costs of water pumping into water supply system, because pumps will not be in function for 24 hours any more.

To a certain extent this system reservoir will act as prime sedimentation chamber, effecting in improvement of water quality at time periods of substantial torrents and turbid water in source. Water utility obligations regarding this issue, that were undertaken upon building of hydro power system on the river Trebišnjica, will be fulfilled by these construction works.

Reservoir is projected to be constructed in two phases. During the first phase a water chamber will be constructed and a waterstop together with whole hydromechanical equipment, chlorination station, reconstruction of hydromechanical equipment for pump station (electro installations and automatics) and replacement of existing pipeline.

Recommendations suggest to complete the works on Project report for sanitary protection of source, ie. to define zones for sanitary protection and to protect source from possible adverse impacts on water quality. Likewise it is necessary to continue with completing the study on quality of natural water along with adequate monitoring. 


\section{References:}

Consortium: Civil Engineering Institute "IG", limted liability company Banjaluka, Hydro Engeineering Institute, limited liability company, Sarajevo, IBIS - Engineering, limted liability company, Banjaluka (2016). Main design of drinking water reservoir at spring Vrelo Oko, Books 1 - 5

Energoinvest Sarajevo (1964). Vodovod Trebinje - Reconstruction - Change of variant solution of intake, Main design, Sarajevo

Geotehnika Zagreb (1979). Reconstruction of pump station Trebinje, Main design , Books I i II, Zagreb

Geotehnika Zagreb (1990). Reconstruction of pump station Vrelo Oko Trebinje, Main design, Zagreb

Gvozdenović T., Furtula V. (2019). Construction of water system reservoir "Vrelo Oko", Journal "ERS", No. 30, Mixed Holding Power Utility of Republic of Srpska, p. 17-18, Trebinje

Milanović P. ( 2006) Karst of East Herzegovina and littoral area of Dubrovnik, Associaction of caver' organizations of Srbija, Belgrade, 2006.

Official Gazette of Republic of Srpska No. 88/17 (2017). Rulebook on hygiene soundness of drinking water, p. Banjaluka, www.slglasnik.org

Vodovod Trebinje (1979). Study of increasing spring "Oko" capacity, Geological survey, Trebinje

Vodovod Trebinje (2019). Records of water puddling at spring Vrelo Oko for period from 2007-2018., Trebinje

Vodovod Trebinje (2019). Annual report on drinking water quality from town water supply system Trebinje for period from 01.01.2018. to 31.12.2018., Trebinje, www.vodovodtrebinje.com

Tamara Gvozdenović

Hydro Power Plants on the river Trebisnjica,

Trebinje,

Bosnia \& Herzegovina tgvozdenovic@henatrebisnjici.co $\underline{\mathrm{m}}$

\section{Vedran Furtula}

Hydro Power Plants on the river Trebisnjica,

Trebinje,

Bosnia \& Herzegovina vfurtula@henatrebisnjici.co $\underline{\mathrm{m}}$
Gojko Krunić

Production and

Management Faculty

Trebinje,

Trebinje,

Bosnia \& Herzegovina

gojko.krunic@fpm.ues.rs.

ba 


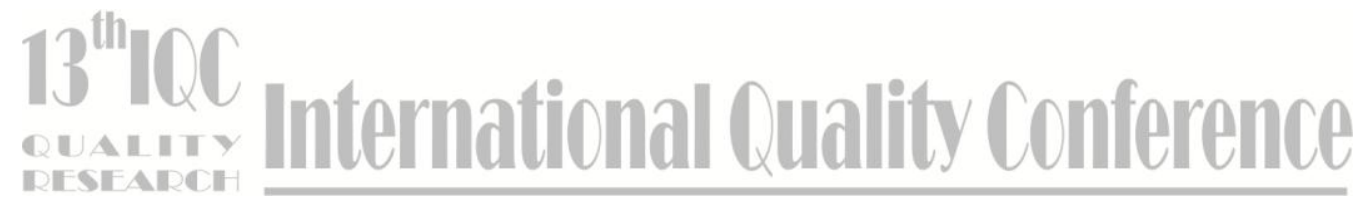

